\section{Light Transmission Through Colored Polyethylene Mulches Affects Weed Populations}

\author{
Mathieu Ngouajio ${ }^{1}$ and Jeremy Ernest \\ Department of Horticulture, Michigan State University, Plant and Soil Sciences \\ Building, East Lansing, MI 48824-1325
}

Additional index words. infrared, optical properties, plasticulture, photoselective mulch, photosynthetically active radiation, PAR

\begin{abstract}
Weed control is one of the benefits associated with the use of plastic mulches used for vegetable production. The mulches decrease light transmission and prevent development of most weed species. Plastics chemistry has developed films varying in their ability to reflect, absorb, and transmit light. Laboratory and field experiments were conducted to 1) measure light transmitted through colored mulches, 2) evaluate weed populations under each mulch type, and 3 ) determine if light transmission could be used as an indicator for weed populations in the field. The polyethylene mulches were black, gray, infrared transmitting brown (IRT-brown), IRT-green, white, and white-on-black (co-extruded white/black). On average, $1 \%, 2 \%, 17 \%, 26 \%, 42 \%$, and $45 \%$ light in the 400 to $1100 \mathrm{~nm}$ range was transmitted through the black, white/black, gray, IRT-brown, IRT-green, and white mulches, respectively. In field experiments, density and dry biomass of weeds growing under the mulches were evaluated. The white mulch had the highest weed density with an average of 39.6 and 155.9 plants $/ \mathrm{m}^{2}$ in 2001 and 2002 , respectively. This was followed by the gray mulch, with 10.4 and 44.1 weed seedlings $/ \mathrm{m}^{2}$ in 2001 and 2002, respectively. Weed density was $<25$ plants $/ \mathrm{m}^{2}$ with the other mulches in both years. Weed infestation was correlated with average light transmission for white, black, white/black, and gray mulches. However, both light quantity and quality were necessary to predict weed infestations with the IRT mulches. Weed infestation under the IRT mulches was better estimated when only wave lengths in the photosynthetically active radiation range (PAR; 400 to $700 \mathrm{~nm}$ ) were considered. Low weed pressure and high light transmission with the IRT mulches would make them appropriate for use in areas where both weed control and soil warming are important factors.
\end{abstract}

Weed competition is one of the major constraints to vegetable production in the United Sates (Bell, 1997). Polyethylene mulches are widely used in vegetable production and have contributed significantly to reduction of losses due to weed competition. Weed suppression under plastic is the result of many factors including 1) prevention of seed germination by reduced light transmission and 2) reduction of weed seedling development due to physical barrier of the mulch or lack of light.

The amount of light transmitted by mulches depends on field exposure, mulch color and other optical properties (Brault et al., 2002). Black plastic has been the standard plastic used by most farmers worldwide (Schales, 1990; Tarara, 2000). However, during the last few years, the plastics industry has developed films

Received for publication 18 Apr. 2003. Accepted for publication 12 Dec. 2003. This research was supported by the Michigan Agricultural Experiment Station (MAES), and the Southwest Michigan Research and Extension Center (SWMREC). Thanks to Kenneth L. Poff and Erik Runkle for their critical comments on the early version of this manuscript. The spectroradiometer was provided by Royal Heins and Erik Runkle. We acknowledge Ronald Goldy, Sieglinde Snapp, and Bernard Zandstra for advice in field experiments and Dave Francis and Mark Hildebrand for their technical assistance.

${ }^{1}$ To whom reprint requests should be addressed; e-mail ngouajio@msu.edu. with different colors and optical properties (Brault et al., 2002; Csizinszky et al., 1995, 1999; Diaz-Perez and Batal, 2002; Gough, 2001; Ham et al., 1993; Hanna, 2000; Paterson, 1998; Tarara, 2000; Schalk and Robbins, 1987). Film color may affect therefore effective weed seed germination, growth, and development under the plastic (Brault et al., 2002; Ham et al., 1993; Paterson, 1998). Knowing the spectral transmittance of colored films may help in understanding their weed suppressive effect (Brault et al., 2002; Paterson, 1998). Such information would help predict weed infestations and assist growers in selecting the appropriate film for their growing conditions. This study was therefore conducted to 1) measure light transmitted through colored polyethylene mulches, 2) evaluate weed populations under each mulch type, and 3) determine if light transmission could be used as an indicator for potential weed populations and growth in the field.
Table 1. Major weeds present at the experimental sites.
Experiments were conducted in the field and laboratory. The mulches were black, gray, infrared transmitting brown (IRT-brown), IRTgreen, white, and white-on-black (co-extruded white/black). All mulches (90 cm wide) were manufactured by North American Film (currently Pliant Corporation, Schaumburg, Ill.) and were $0.038 \mathrm{~mm}$ thick except the black mulch that was $0.025 \mathrm{~mm}$.

Laboratory experiments. A clean $30 \times$ $30-\mathrm{cm}$ piece from each film was used for light transmission measurements. The analyses were conducted on new films and on used films after about 45 to $50 \mathrm{~d}$ of field exposure. Light transmission in the 400 to $1100 \mathrm{~nm}$ range was measured using a spectroradiometer (LI-1800; LI-COR, Lincoln, Nebr.) (Decoteau et al., 1988; Ham et al., 1993; Brault et al., 2002). The light source was a 60-W incandescent bulb (General Electric Co. Cleveland, Ohio) placed $50 \mathrm{~cm}$ from the spectroradiometer. The spectrum of incandescent lamps covers the range of wavelengths measured (Ryer, 1997). Each film was scanned at 1-nm increments. Each scan was preceded by ablank scan (with no plastic).Light transmission was determined by the percentage transmission through one layer of plastic compared with the blank scan. (Brault et al., 2002).

Field experiments. Field studies were conducted in summer 2001 and 2002 (June to September) on Oakville fine sand soil at Michigan State University, Southwest Michigan Research and Extension Center, Benton Harbor. All mulches were laid on $60-\mathrm{cm}$ wide raised beds, using a combined bed shaper plastic layer. Fresh-market 'Mountain Spring' tomato (Lycopersicon esculentum Mill.) was transplanted into different colored plastic mulches and grown using drip-irrigation and fertigation. The experimental design was a randomized complete block with six plastic mulches and four replications. Individual plots were $5 \mathrm{~m}$ wide and $10 \mathrm{~m}$ long with three beds. About 45 to $50 \mathrm{~d}$ after mulch laying, a $60 \times 90-\mathrm{cm}$ section including a tomato plant, was cut in the middle bed of each treatment. All weeds growing under the mulches in the sampled area were counted and harvested for biomass determination as described by Brault et al. (2002) (Table 1). Weed density and biomass data were transformed prior to analysis using a square-root transformation [SQRT $(\mathrm{X}+0.5)$ ]. Transformed data were subjected to analysis of variance and means separated using LSD at 5\% level of probability. Linear regression analysis was performed between light transmission and weed density data, and between light transmission and weed biomass data. Several models were tested in preliminary studies, and the following equation was the simplest equation that

\begin{tabular}{lll}
\hline Scientific name & Common name & Family \\
\hline Elytrigia repens (L.) Nevski & Quackgrass & Gramineae \\
Spergula arvensis L. & Corn spurry & Caryophyllaceae \\
Vicia villosa Roth & Hairy vetch & Leguminosae \\
Chenopodium album L. & Common lambsquarters & Chenopodiaceae \\
Amaranthus spp & Pigweeds & Amaranthaceae \\
Portulaca oleracea L. & Common purslane & Portulacaceae \\
\hline
\end{tabular}




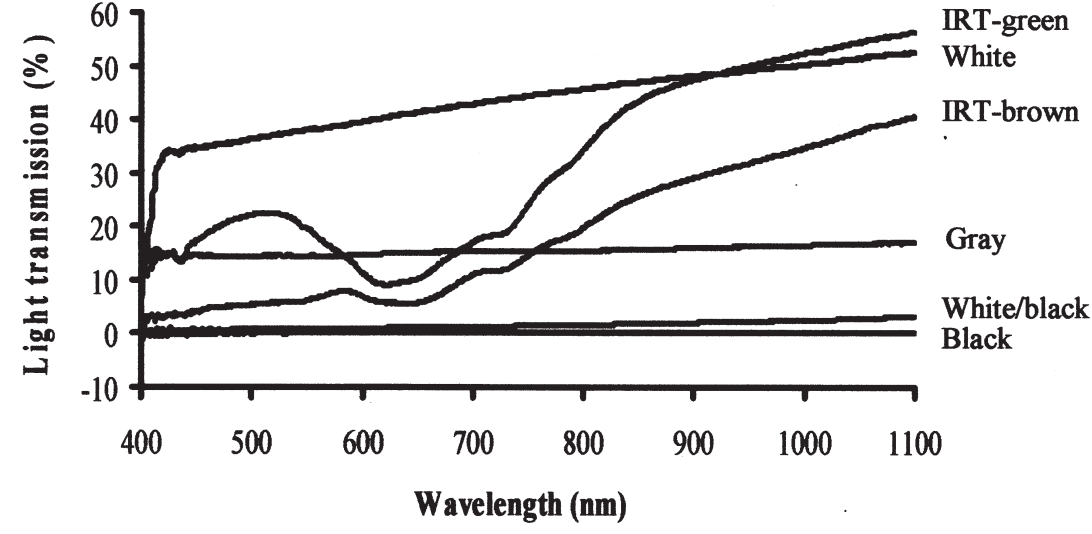

Fig. 1. Amount of light (\%) transmitted through colored plastic mulches. The mulches are black, white, gray, white-on-black (white/black), infrared transmitting green (IRT-green), and infrared transmitting brown (IRT-brown).

Table 2. Light transmission through colored mulches and density and biomass of weeds under the plastics in 2001 and 2002 .

\begin{tabular}{|c|c|c|c|c|c|c|}
\hline \multirow[b]{2}{*}{ Film color ${ }^{\mathrm{y}}$} & \multicolumn{2}{|c|}{ Light transmission $(\%)^{z}$} & \multicolumn{2}{|c|}{ Weed density $\left(\mathrm{no} . / \mathrm{m}^{2}\right)$} & \multicolumn{2}{|c|}{ Weed biomass $\left(\mathrm{g} \cdot \mathrm{m}^{-2}\right)$} \\
\hline & PAR & Total & 2001 & 2002 & 2001 & 2002 \\
\hline White & 37 & 48 & $39.6 \mathrm{a}$ & $155.9 \mathrm{a}$ & $159.7 \mathrm{a}$ & $210.0 \mathrm{a}$ \\
\hline Black & 0 & 1 & $3.6 \mathrm{c}$ & $20.8 \mathrm{c}$ & $0.1 \mathrm{~b}$ & $0.8 \mathrm{c}$ \\
\hline White/black & 1 & 2 & $3.8 \mathrm{bc}$ & $21.7 \mathrm{c}$ & $0.1 \mathrm{~b}$ & $16.7 \mathrm{bc}$ \\
\hline Gray & 15 & 17 & $10.4 \mathrm{~b}$ & $44.1 \mathrm{~b}$ & $0.6 \mathrm{~b}$ & $37.4 \mathrm{~b}$ \\
\hline IRT green & 16 & 42 & $6.7 \mathrm{bc}$ & $24.2 \mathrm{bc}$ & $1.7 \mathrm{~b}$ & $7.7 \mathrm{c}$ \\
\hline IRT brown & 6 & 26 & $9.2 \mathrm{bc}$ & $18.4 \mathrm{c}$ & $1.0 \mathrm{~b}$ & $2.4 \mathrm{c}$ \\
\hline
\end{tabular}

${ }^{\mathrm{z}}$ Mean separation based on square root transformation [SQRT $\left.(\mathrm{X}+0.5)\right]$. Means in the same column followed by the same letter are not significantly different $(P \leq 0.001)$. Light transmission is the average for wave lengths 400 to $1100 \mathrm{~nm}$ (total) or the average for photosynthetically active radiations (PAR; 400 to $700 \mathrm{~nm}$ ).

y IRT $=$ infrared transmitting, NA = not applicable.

adequately fitted the data: $\mathrm{Y}=\mathrm{a}+\mathrm{bx}^{2}$, where $Y$ is weed density or biomass, $x$ is light transmission, $a$ is weed density or weed biomass in the absence of light, and $b$ is a shape coefficient. All statistical analyses were conducted using SAS (SAS Institute, 1994).

\section{Results and Discussion}

Light transmission. Light transmission through the mulches was only minimally affected by mulch exposure in the field. New mulches and those collected from the field after 45 to $50 \mathrm{~d}$ of exposure had comparable light transmissions (data not shown) Only data for new mulches are reported herein.

Mulch type highly affected the amount of light transmitted (Fig.

Fig. 2. Heat accumulation measured as air or soil $(2 \mathrm{~cm})$ degree-days (DD) during the first month after tomato transplanting through colored mulches. Air DD and soil DD were calculated using the formula $\mathrm{DD}=1 / 2\left(\mathrm{~T}_{\mathrm{Max}}+\mathrm{T}_{\mathrm{Min}}\right)-\mathrm{T}_{\mathrm{ba}}$ where $\mathrm{T}_{\text {Max }}, \mathrm{T}_{\text {Min }}$, and $\mathrm{T}_{\text {base }}$ are daily maximum, daily minimum, and base temperatures $\left(10{ }^{\circ} \mathrm{C}\right)$, respectively. The mulches are black (B), white (W), gray (G), white-on-black (W/B), infrared transmitting green (IRT-green), and infrared transmitting brown (IRT-brown).
1 , Table 2). On average, $1 \%$ to $48 \%$ light in the 400 to $1100 \mathrm{~nm}$ waveband was transmitted through the mulches. The black and white/black mulches had the greatest opacity, with only 1 and $2 \%$ of the incident light transmitted, respectively. The gray mulch transmitted $17 \%$, IRT-brown $26 \%$, IRT-green $42 \%$, and white $48 \%$. Similar light transmission has been previously reported for the black, gray, white/black, and IRT mulches from different manufacturers (Brault et al., 2002; Paterson, 1998).

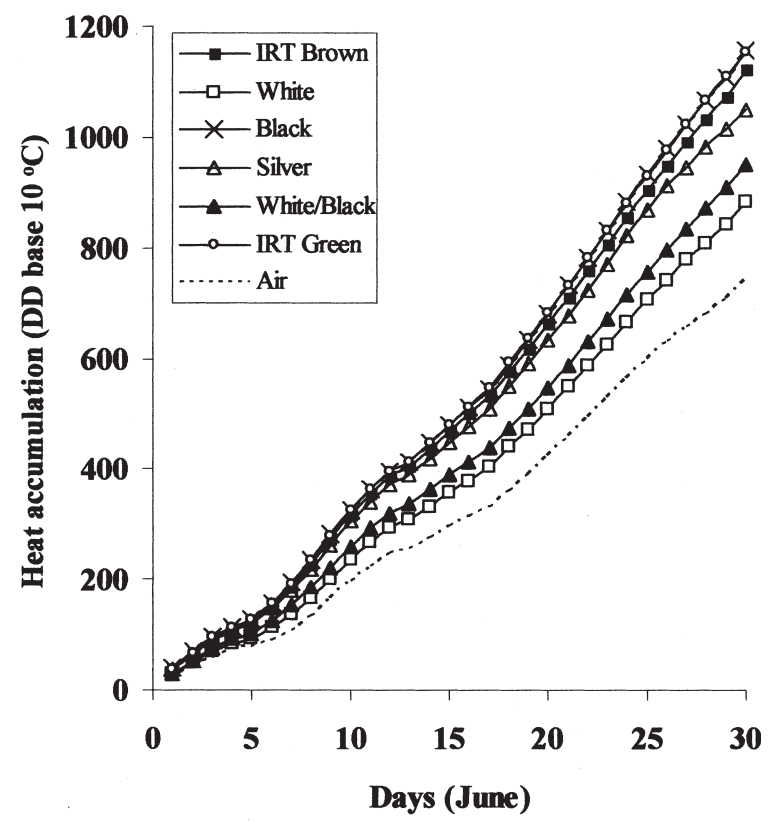

Light transmission in the PAR (photosynthetically active radiation) waveband was between $0 \%$ for the black mulch and $37 \%$ for the white mulch (Table 2). The IRT mulches transmitted less light in the PAR waveband compared to the 400 to $1100 \mathrm{~nm}$ waveband. Light transmission decreased from $42 \%$ to $16 \%$ for the IRT-green mulch when PAR waveband was used compared to the full spectrum. The reduction was from $26 \%$ to $6 \%$ for the IRTbrown mulch.

Weed populations. Weed density and biomass varied with mulch type (Table 2). During both growing seasons, a large number of weeds thrived under the white mulch. In 2001, about 40 weeds $/ \mathrm{m}^{2}$ with a dry weight of $159.7 \mathrm{~g} \cdot \mathrm{m}^{-2}$ were recorded in plots covered with the white mulch. In 2002, weed density under the white mulch was 156 plants $/ \mathrm{m}^{2}$ with a corresponding biomass of $210 \mathrm{~g} \cdot \mathrm{m}^{-2}$. All other mulches had reduced weed infestations. Grasses were the main weeds, with quackgrass (Elytrigia repens) being the most prominent species. The mulch was able to resist the lifting effect of this species despite its heavy infestation. By acting as a physical barrier, the white mulch kept quackgrass competition low, limiting tomato yield losses (data not presented).

Seed germination and seedling growth can be affected by both soil temperature and light (Fortin and Poff, 1990; Paterson, 1998). Paterson (1998) showed increased suppression of purple nutsedge (Cyperus rotundus) with photoselective mulches compared with opaque mulches. Furthermore, the difference in weed suppression was not attributed to soil solarization effects from the photoselective mulches (Paterson, 1998). In our study, soil temperature under the white and the white/black mulches for example, was similar (Fig. 2) and yet weed populations under the mulches were different (Figs. 3 and 4). This suggests that the large weed population under the white plastic was due to its high light transmission and not to differences in soil temperature. This relationship between light transmission and weed populations may be more complex with photoselective mulches. For example, total light transmitted by the IRT-green mulch and white mulch was similar, but weed density and weed biomass were significantly lower under the IRT-green mulch (Table 2). This suggests that, for weed germination and development, the wavelengths transmitted through the plastic could be as important as the total amount of light transmitted.

Prediction of weed population using light transmission. Linear regression analysis showed a weak relationship between average light transmission and weed density or biomass for light in the 400 to $1100 \mathrm{~nm}$ range (Fig. 3). The coefficients of determination were 0.49 and 0.50 for the regression between light transmittance and weed density and the regression between light transmittance and weed biomass, respectively. Data from the two IRT mulches did not fit because they have low PAR transmission. Removing data on the IRT mulches from the analysis increased the coefficients of determination from 0.49 to 0.93 and from 0.50 to 0.96 for data on weed density and weed biomass, respectively (Figure 3). This is an indication that unlike the 


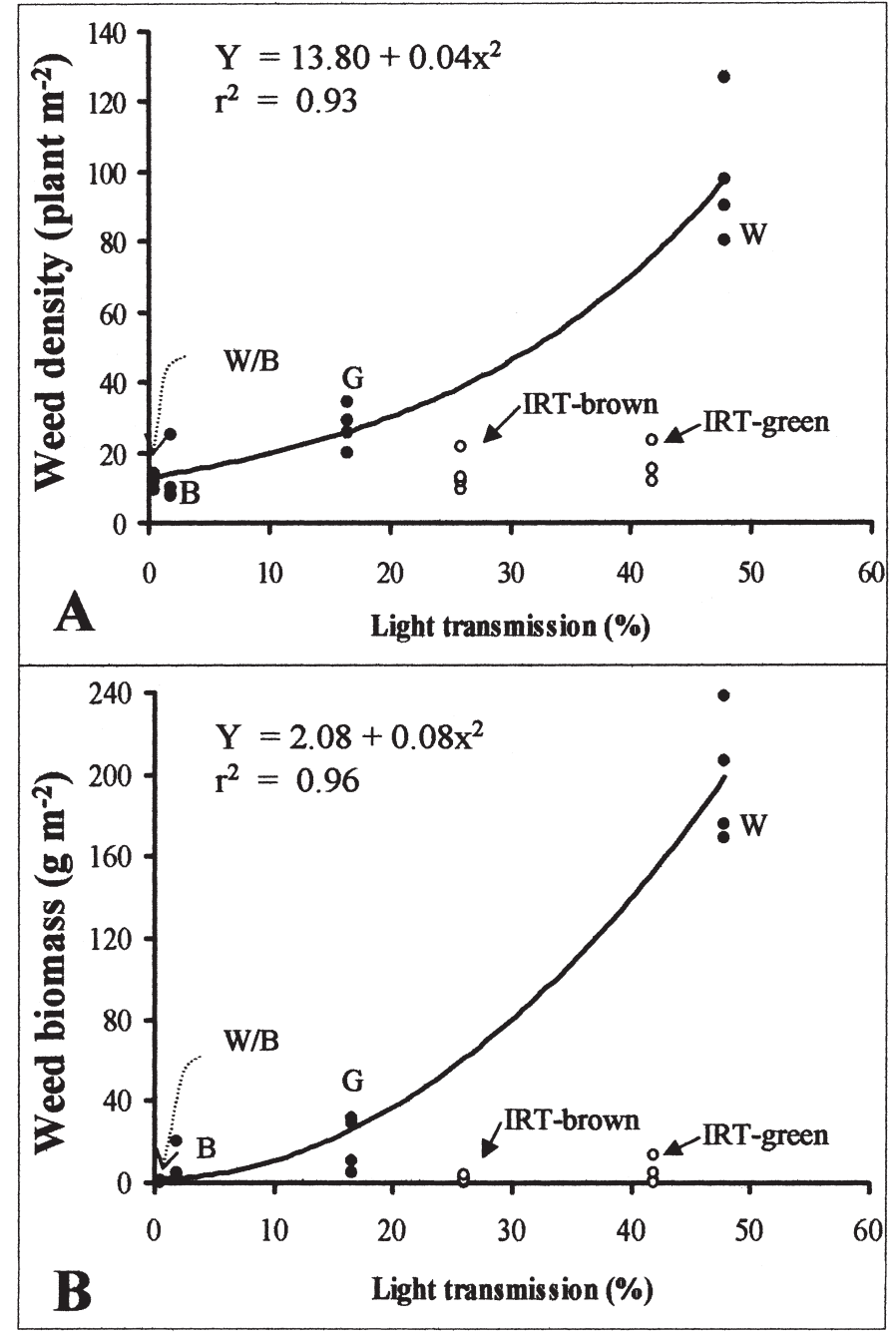

Fig. 3. Regression between light transmission in the 400 to $1100 \mathrm{~nm}$ range through colored plastic mulches and weed density (A) or weed biomass (B). The mulches are black (B), white (W), gray (G), white-on-black (W/B), infrared transmitting green(IRT-green), and infrared transmitting brown (IRT-brown). The regression parameters on the graph were obtained from analyses without data on the IRT mulches. When data on the IRT mulches were included in the regressions, the equations were $\mathrm{y}=8.80+0.03 \mathrm{x}^{2}$ (weed density) and $\mathrm{y}=0.00+$ $0.05 \mathrm{x}^{2}$ (weed biomass) and the $r^{2}$ values were 0.49 for weed density and 0.50 for weed biomass.

other mulches, total light transmission through the IRT mulches cannot be used as an accurate indicator of weed populations in the field.

Separate regressions were conducted using only light in the PAR waveband (Fig. 4). Using average light transmission in the PAR range, all mulches adequately fitted the regression model. The coefficients of determination were 0.91 for the regression between light transmission and weed density and 0.93 for the regression between light transmission and weed biomass.

\section{Conclusions}

Colored polyethylene mulches varied greatly in their ability to transmit incident light. The transmitted light affects weed seed germination and growth, determining weed pressure under plastic mulch. Light transmission can therefore
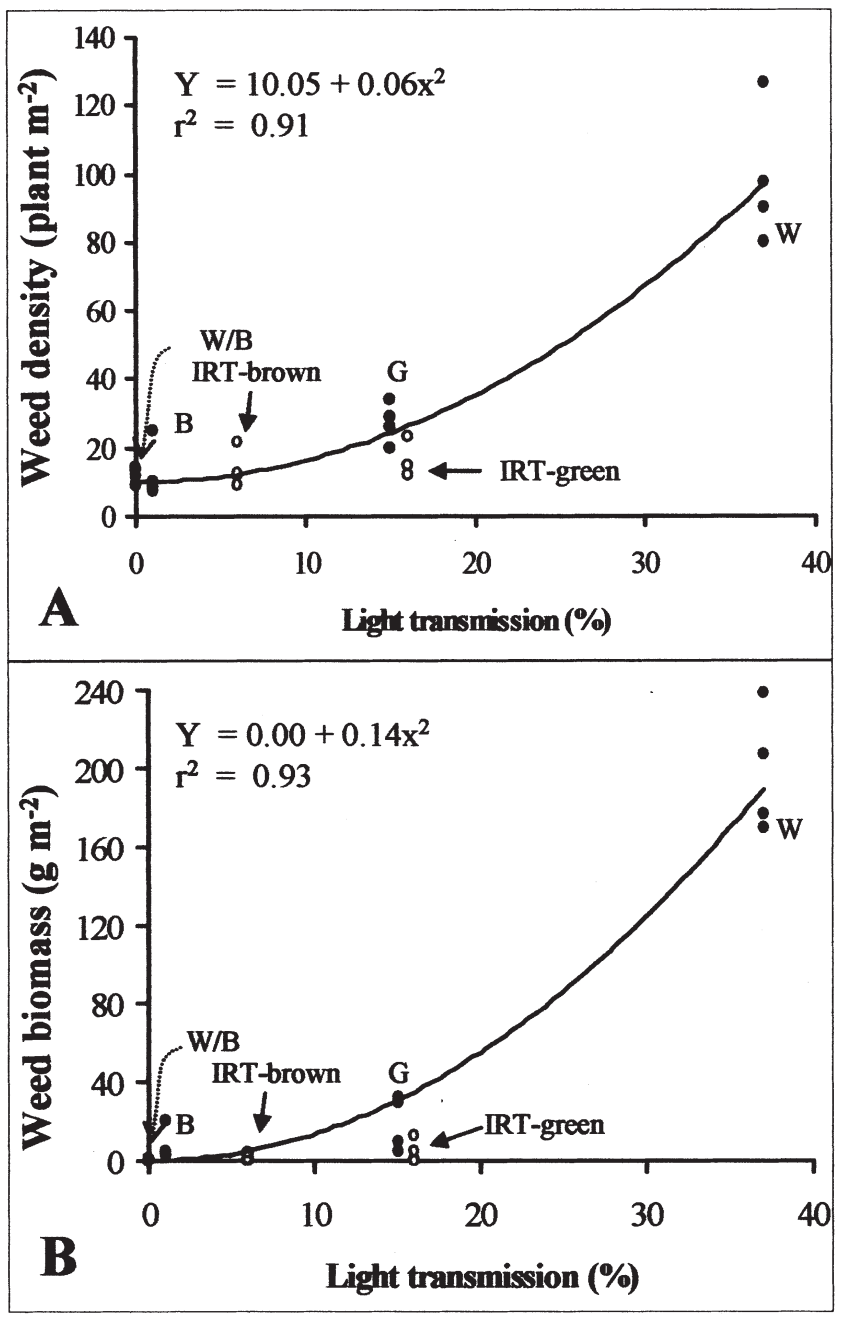

be used as an indicator of weed infestations in the field. However, when wavelength selective mulches are used, accurate estimation of weed populations can be achieved only when light in the PAR waveband is considered. These results could be used in the development of new mulches as an early screening method to quickly estimate their effects on weed populations prior to field testing. Field evaluation is time consuming and expensive. These results could also be used as additional criteria to help growers select the most appropriate mulch for their growing conditions.

\section{Literature Cited}

Bell, C.E. 1997. Weed management in vegetable crops, p. 30-41. In: M.E. McGiffen (ed.). Weed management in horticultural crops. ASHS Press, Alex., Va.

Brault, D., K.A. Stewart, and S. Jenni. 2002. Optical properties of paper and polyethylene mulches used for weed control in lettuce. HortScience 37:87-91.

Csizinszky, A.A., D.J. Schuster, and J.B. Kring. 1995. Color mulches influence yield and insect pest populations in tomatoes. J. Amer. Soc. Hort. Sci. 120:778-784.

Csizinszky, A.A.,D.J. Schuster, and J.E. Polston. 1999. Effect of ultraviolet-reflective mulches on tomato yields and on the silverleaf whitefly. HortScience 34:911-914.

Decoteau, D.R., M.J. Kasperbauer, D.D. Daniels, and P.G. Hunt. 1988. Plastic mulch color effects on reflected light and tomato plant growth. Scientia Hort. 34:169-175.

Diaz-Perez, J.C. and K.D. Batal. 2002. Colored plastic film mulches affect tomato growth and yield via changes in root-zone temperature. J. Amer. Soc. Hort. Sci.
Fig. 4. Regression between light transmission in the 400 to $700 \mathrm{~nm}$ range through colored plastic mulches and weed density $(\mathbf{A})$ or weed biomass (B). The mulches are black (B), white (W), gray (G), white-on-black (W/B), infrared transmitting green (IRT-green), and infrared transmitting brown (IRT-brown).

127:127-132.

Fortin, M.C.A. and K.L. Poff. 1990. Temperature sensing by primary root of maize. Plant Physiol. 94:367-369.

Gough, R.E. 2001. Color of plastic mulch affects lateral root development but not root system architecture in pepper. HortScience 36:66-68.

Ham, J.M., G.J. Kluitenberg, and W.J. Lamont. 1993. Optical properties of plastic mulches affect the field temperature regime. J. Amer. Soc. Hort. Sci. 118:188-193.

Hanna, H.Y. 2000. Double-cropping muskmelons with nematode-resistant tomatoes increases yield, but mulch color has no effect. HortScience 35:1213-1214.

Paterson, D.T. 1998. Suppression of purple nutsedge ( $C y$ perus rotundus) with polyethylene film mulch. Weed Technol. 12:275-280.

SAS Institute. 1994. SAS/STAT user's guide. version $6.4^{\text {th }}$ ed. SAS Inst., Cary, N.C.

Ryer, A. 1997. Light measurement handbook. International Light Inc., Newburyport, Mass. http://www.intl-light. com/handbookthanks.html.

Schales, F.D. 1990. Agricultural plastics use in the United States. Proc. $11^{\text {th }}$ Intl. Congr. Plast. Agr. J. p. 54-56.

Schalk, J.M. and M.L. Robbins. 1987. Reflective mulches influence plant survival, production, and insect control in fall tomatoes. HortScience 22:30-32.

Tarara, J.M. 2000. Microclimate modification with plastic mulch. HortScience 35:169-180. 